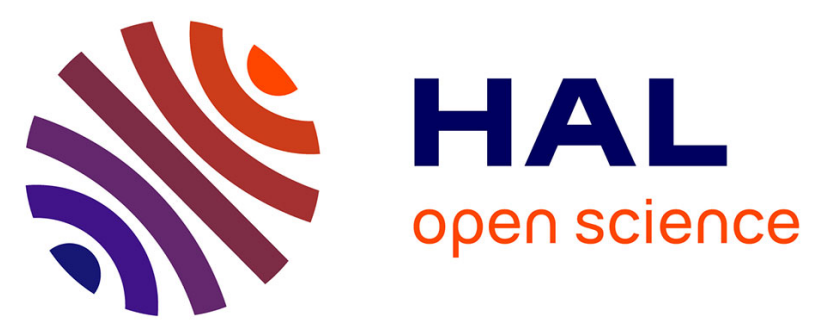

\title{
Variability of traits and bioactive compounds in the fruit and pulp of six mamey apple (Mammea americana L.) accessions
}

\author{
Armelle Peroumal, Sandra Adenet, Katia Rochefort, Louis Fahrasmane, \\ Guylène Aurore
}

\section{To cite this version:}

Armelle Peroumal, Sandra Adenet, Katia Rochefort, Louis Fahrasmane, Guylène Aurore. Variability of traits and bioactive compounds in the fruit and pulp of six mamey apple (Mammea americana L.) accessions. Food Chemistry, 2017, 234, pp.269-275. 10.1016/j.foodchem.2017.04.145 . hal-01606022

\section{HAL Id: hal-01606022 \\ https://hal.science/hal-01606022}

Submitted on 25 May 2020

HAL is a multi-disciplinary open access archive for the deposit and dissemination of scientific research documents, whether they are published or not. The documents may come from teaching and research institutions in France or abroad, or from public or private research centers.
L'archive ouverte pluridisciplinaire HAL, est destinée au dépôt et à la diffusion de documents scientifiques de niveau recherche, publiés ou non, émanant des établissements d'enseignement et de recherche français ou étrangers, des laboratoires publics ou privés.

\section{다(1)(2)}

Distributed under a Creative Commons Attribution - ShareAlikel 4.0 International 


\title{
Variability of traits and bioactive compounds in the fruit and pulp of six mamey apple (Mammea americana L.) accessions
}

\author{
Armelle Péroumal $^{\mathrm{a}}$, Sandra Adenet ${ }^{\mathrm{b}}$, Katia Rochefort ${ }^{\mathrm{b}}$, Louis Fahrasmane ${ }^{\mathrm{c}}$, Guylène Aurore ${ }^{\mathrm{d}, *}$ \\ a Université des Antilles, UMR 1270 QUALITROP, F-97 110 Pointe-à-Pitre, France \\ ${ }^{\mathrm{b}}$ Pôle Agroalimentaire Régional de Martinique, Habitation Petit Morne n³75, F-97 232 Le Lamentin, France \\ ' INRA, UMR 1270 QUALITROP, Domaine Duclos Prise d'eau, F-97 170 Petit-Bourg, France \\ ${ }^{\mathrm{d}}$ Université des Antilles, COVACHIM M2E (EA 3592), UFR SEN, Campus de Fouillole, F-97 110 Pointe-à-Pitre, France
}

\section{A R T I C L E I N F O}

\section{Article history:}

Received 21 October 2016

Received in revised form 4 March 2017

Accepted 24 April 2017

Available online 27 April 2017

\section{Keywords:}

Mammea americana $\mathrm{L}$.

Mamey

Physical analysis

Physico-chemical analyses

Biochemical analyses

Total phenolics content

Total flavonoids

Principal component analysis (PCA)

Cluster analysis (CA)

\begin{abstract}
A B S T R A C T
Our objective was to compare fruit morphology, physico-chemistry and bioactive compounds content of the edible pulp of six Mammea americana accessions. The results showed that this fruit was rather big, weighing on average 600 to $1100 \mathrm{~g}$ depending on the accession, and spherical to oblate-shaped. The pulp represented between 50 and $70 \%$ of the weight of the whole fruit. The pulp adhered only partially to the seeds in 5 of the 6 accessions studied, while the last one exhibited full adherence. The fresh pulp was acidic, sweet, succulent and crunchy. The fruits studied had a variety of qualities, providing various opportunities for post-harvest uses: fruit salads, nectar preparation, jams and jellies, or export. We have established for the first time the total phenolic compounds and total flavonoids contents in the pulp of mamey apple fruits. The pulp colour was highly correlated with total phenolic compounds and total carotenoids contents.
\end{abstract}

(c) 2017 Elsevier Ltd. All rights reserved.

\section{Introduction}

Tropical America has a rich diversity of plants providing a source of edible fruits more or less rich in antioxidants, such as carotenoids, vitamin $\mathrm{C}$ and phenolic compounds. However, for many tropical fruits limited information on the nutritional value and the characteristics of their accessions is available. Mammea americana Linn. (1753) (family Clusiaceae) is a tree native to Tropical America. It is grown for the physical and chemical properties of the edible pulp of its fruit, a drupe commonly known as mamey, mamey apple, mamey de Santo Domingo or South American apricot (Campbell, 2005). The mamey fruit pulp seems similar to the pulp of the apricot Prunus armeniaca. The tree is often a component of home gardens, grown for its pulpy fruits. The ripeness of the fruit is traditionally determined by its dropping time. The fruit is climacteric. The skin of ripe fruits is often used in rural areas as a ripening agent in traditional ripening processes of other fruits.

\footnotetext{
* Corresponding author at: Université des Antilles et de la Guyane, COVACHIM M2E (EA 3592), UFR SEN, Campus de Fouillole, F-97 110 Pointe-à-Pitre, France.

E-mail addresses: armelle_peroumal@yahoo.fr (A. Péroumal), adenet@parm. asso.fr (S. Adenet), rochefort@parm.asso.fr (K. Rochefort), Louis.Fahrasmane@ antilles.inra.fr (L. Fahrasmane), guylene.aurore@univ-antilles.fr (G. Aurore).
}

Mamey's pulp is consumed raw as a dessert or used to prepare sweet dishes and beverages, throughout Central America and the Caribbean (Yahia and Guttierrez-Orozco, 2011; Manzano-Mendez \& Dris, 2001). The Mammea americana L. tree can reach up to $25 \mathrm{~m}$ in height. Its trunk and branches are covered with a dark brown, rough bark. There are barren trees bearing only male flowers, and trees with morphologically perfect flowers that are functionally female (Dunthorn, 2004; Morton, 1962; Le Bellec and Le Bellec, 2007). The fruit is a big spherical to oblate drupe that may reach $10-25 \mathrm{~cm}$ in diameter wrapped in a thick brown skin with a leathery appearance. Beneath the skin, there is a thin whitish membranous mesocarp, often bitter, attached to the endocarp, the edible pulp. The pulp is yellow to orange, non-fibrous, crunchy and slightly juicy. Its adherence to the seed(s) depends on the accession (Le Bellec and Le Bellec, 2007). The fruit may contain one to four ellipsoids seeds which are russet-brown with a fibrous testa.

The mamey fruit is also well known for the insecticidal activity contained in the kernel of its seeds. Most studies have been carried out on the kernel of the mature seeds, which is a rich source of insecticidal coumarins (Jones \& Plank, 1945; Crombie, Games, Haskins \& Reed, 1972; Boulogne et al., 2011; Reyes-Chilpa et al., 
2008; Yang, Jiang, Reynertson, Basile, \& Kennelly, 2006). Different parts of the tree have also been investigated for their antioxidant, cytotoxic, antibacterial, molluscicidal and antiulcer activities (Gallo, Allee, \& Gibson, 1996; Melendez \& Capriles, 2002; Toma, Hiruma-Lima, Guerrero \& Souza Brito, 2005).

Gervais and Lavigne (2007) studied the physical characteristics and physico-chemical properties of mamey fruits, while De Rosso and Mercadante (2007), Guiffrida et al. (2015) determined their carotenoid composition. Mamey fruits are consumed and prized for their flavour (Morales \& Duque, 2002) and attractive yellow to orange colour. Few reports deal with mamey fruit pulp and its phenolic compounds content. Our work focused on the analysis and comparison of the morphological and physico-chemical traits of the fruits, the biochemical content and the bioactive compounds of the fruits pulp of six accessions of mamey grown in the same field under comparable ecological conditions, on the island of Martinique (French West Indies). The determination of the physical and chemical properties of mamey fruits is necessary in order to select elite accessions producing fruits suitable for the processing industry.

\section{Materials and methods}

\subsection{Sample collection and preparation}

Fruits from six mamey (Mammea americana L.) accessions were sampled (Sonson, Pavé 11, Lézarde, Ti Jacques, Escouët, Antonio). These accessions are recognized by the people of Martinique (French West Indies) as interesting trees bearing high-quality fruits. The accessions, except for Antonio, were described by Gervais and Lavigne (2007), botanists from CIRAD. They included the Antonio accession in their orchard as an interesting mamey apple. The six accessions were propagated by grafting to give small tress bearing fruits within easy reach. Over a period from February to July 2011, 30 ripe fruits were randomly collected after dropping from ten grafted trees for each accession grown on the same experimental site, i.e. under the same agropedoclimatic conditions, on Martinique (French West Indies). The skin, pulp and seeds were manually separated from every fruit, and were weighed separately. The pulp was cut into pieces, immediately frozen in liquid nitrogen and stored at $-80{ }^{\circ} \mathrm{C}$ until chemical analysis. All the experiments were performed in triplicate.

For polyphenol determination, the samples were freeze-dried for 5 days. The dried pulp was reduced to powder using a commercial blender. The powder samples were stored at $-80^{\circ} \mathrm{C}$ until analysis.

\subsection{Physical analyses}

From each mamey accession, the 30 ripe fruits collected underwent individual physical analysis.

\subsubsection{Morphological characteristics}

The equatorial and longitudinal circumferences were measured by means of a tape measure with a precision of $1 \mathrm{~mm}$. The longitudinal circumference (LC) was measured at the polar axis of the fruit, i.e., between the apex and the stem. The equatorial circumference (EC) was measured in the direction perpendicular to the polar axis. The shape of the fruit was defined by the ratio equatorial circumference/longitudinal circumference (EC/LC).

The fruits were weighed on a balance with a precision of $0.1 \mathrm{~g}$. The pulp/seed ratio was obtained by dividing the pulp weight by the seed weight.

For each fruit, the number of seeds was counted and the pulp adherence was determined by manual pulling. A score was assigned to define the pulp adherence: 5 for strong adherence, 2.5 for partial adherence and 0 for no pulp adherence to the seeds.

\subsubsection{Physical measurements}

The whole fruit firmness was evaluated according to the method described by Bashir and Abu-Goukh (2003), with some modifications. A LLOYD INSTRUMENTS TA PlusTexture Analyser was used to evaluate the maximum force required for a Magness-Taylor probe (diameter: $8 \mathrm{~mm}$ ) to penetrate the fruit to a depth of $3 \mathrm{~mm}$ at a rate of $30 \mathrm{~mm} / \mathrm{min}$. To this end a fruit was cut in half, and stabilized on the measuring apparatus. Results were expressed in Newtons $(\mathrm{N})$.

The pulp colour was evaluated using a CR-410 hand-held chromameter (Konica Minolta). Colour values for each fruit were calculated as the mean of three measurements taken from opposite sides at the equatorial region of the fruit. Results were reported as $L^{*}, a^{*}$ and $b^{*}$ values.

\subsection{Chemical analyses}

Samples were kept at $4{ }^{\circ} \mathrm{C}$ overnight after removing them from $-80^{\circ} \mathrm{C}$ before analysis. All the chemical analyses were carried out on the pulp of 30 ripe fruits from ten trees for each of the six mamey accessions studied.

\subsubsection{Determination of total dry matter (TDM), soluble solids content} (SSC), $\mathrm{pH}$ and titratable acidity (TA)

The total dry matter (TDM) was obtained by determining the moisture content (MT) of the pulp. The moisture content was evaluated by the direct drying method as per Chew, Nagendra Prasad, Amin, Azrina, and Lau (2011) with some modifications. The homogenized pulp sample ( $2 \mathrm{~g}$ ) was dried overnight in an airoven set at $70^{\circ} \mathrm{C}$ until constant sample weight was obtained. The moisture content was defined by the difference between initial weight and constant weight after drying. The total dry matter (TDM) was expressed as $\mathrm{g} / 100 \mathrm{~g}$ fresh weight (FW) of fruit, and was calculated as follows: TDM $=100-\mathrm{MT}$

Physico-chemical measurements were performed at room temperature $\left(20^{\circ} \mathrm{C}\right) . \mathrm{pH}$ and soluble solids content (SSC) were measured according to the method described by Bartolomé, Rupérez, and Fúster (1995) with slight modifications. The $\mathrm{pH}$ of the homogenized pulp sample ( $5 \mathrm{~g}$ ) was determined with an Inolab $\mathrm{pH}$ meter. An automatic digital refractometer (Bellingham RFM 340) was used to measure the pulp soluble solids content (SSC). Results were reported as degrees Brix. To determine the titratable acidity (TA), the sample $(10 \mathrm{~g})$ was homogenized (Ultra-Turax) with $40 \mathrm{ml}$ deionized water. The filtrate obtained was titrated with $0.1 \mathrm{~N}$ $\mathrm{NaOH}$ up to $\mathrm{pH} 8.1 \pm 0.2$, and measured with an Inolab $\mathrm{pH}$ meter (Al-Maiman \& Ahmad, 2002). Acidity was expressed as meq/100 ml sample.

\subsubsection{Determination of total phenolics content (TPC) and total flavonoids content (TFC)}

The extraction of total phenolic compounds was performed as follows: the sample ( $5 \mathrm{~g}$ ) was homogenized with $50 \mathrm{ml}$ of extraction solvent (70:30 v/v water/acetone) for $1 \mathrm{~min}$. Ultrasound was applied for $30 \mathrm{~min}$ at $4{ }^{\circ} \mathrm{C}$, by means of an ultrasound bath (Bioblock Scientific T $460 \mathrm{H})(35 \mathrm{kHz}, 85 \mathrm{~W})$. The mixture was then filtered $(0.45 \mu \mathrm{m}$, Whatman). The total phenolics content (TPC) and total flavonoids content (TFC) were determined on the raw extract obtained after filtration.

The total phenolics content was determined according to the Folin-Ciocalteu method (Georgé, Brat, Alter, \& Amiot, 2005; Singleton \& Rossi, 1965). An aliquot $(100 \mu \mathrm{l})$ of appropriately diluted extract was added with $2.5 \mathrm{ml}$ of water-diluted FolinCiocalteu reagent (1/10). After $2 \mathrm{~min}$ at room temperature, $2 \mathrm{ml}$ 
of sodium carbonate solution $(75 \mathrm{~g} / \mathrm{l})$ was added to the mixture. The mixture was incubated for $15 \mathrm{~min}$ at $50^{\circ} \mathrm{C}$. Finally, extracts were cooled in a water-ice bath and the absorbance at $760 \mathrm{~nm}$ of the reaction mixture was measured against a blank using a Perkin Elmer EZ 301 UV/VIS spectrophotometer. The Folin-Ciocalteu reagent can interact with other different reducing non-phenolic substances (reducing sugars, ascorbic acid and amino acids). These interfering water-soluble components can lead to overestimation of phenolics content. Solid phase extraction (Oasis HLB) was performed on the raw extract to eliminate interference. The same Folin-Ciocalteu reagent treatment was applied on the washing extract containing interfering substances. Gallic acid (0-600 mg/ 1) was used as standard and the results were expressed as mg gallic acid equivalent (GAE)/100 g FW of fruit.

The total flavonoids content (TFC) of raw extract was based on the aluminum chloride colorimetric assay described by Lamaison and Carnet (1990). $1 \mathrm{ml}$ of raw extract was mixed with $1 \mathrm{ml}$ of $2 \%$ aluminum chloride. After $10 \mathrm{~min}$ at room temperature, the absorbance of the reaction mixture was measured at $415 \mathrm{~nm}$ against a blank using a Perkin Elmer EZ 301 UV/VIS spectrophotometer. Quercetin $(0-70 \mathrm{mg} / \mathrm{l})$ was used as the standard, and the data were reported as $\mathrm{mg}$ quercetin equivalent $(\mathrm{QE}) / 100 \mathrm{~g}$ FW of fruit.

\subsubsection{Determination of ascorbic acid content ( $A A C)$}

Acid ascorbic content was analyzed by high-performance liquid chromatography with pre-column derivatization according to the standard: NF Norme Française (2011). After enzymatic oxidation of ascorbic acid to dehydroascorbic acid, the latter was condensed with $o$-phenylenediamine (OPDA) to its fluorophore derivative quinoxaline. The latter was separated on a reversed-phase HPLC column and detected fluorometrically. The sample $(2 \mathrm{~g})$ was homogenized with $50 \mathrm{ml}$ of trichloroacetic acid $(0.3 \mathrm{M})$ by magnetic stirring for $30 \mathrm{~min}$. The mixture was then filtered $(0.45 \mu \mathrm{m}$, Whatman). The extract was introduced into an amber glass container with sodium acetate $(4.5 \mathrm{M})$ and ascorbate oxidase. After $10 \mathrm{~min}$ at $37^{\circ} \mathrm{C}$, OPDA solution $(0.001 \mathrm{~g} / \mathrm{ml})$ was added and the mixture was maintained at $37^{\circ} \mathrm{C}$ for $30 \mathrm{~min}$. The derived sample was filtered through PVDF filter $(0.45 \mu \mathrm{m})$ before $10 \mu \mathrm{l}$ of the sample was injected into an Agilent 1100 series HPLC system (Germany) equipped with an isocratic pump (model G1310A) and fluorescence detector (model G1321A). Ascorbic acid was separated on a Restek $\mathrm{C}_{18}$ column $(250 \times 6 \mathrm{~mm}, 5 \mu \mathrm{m})$ fitted with a $\mathrm{C}_{18}$ guard column $(30 \times 6 \mathrm{~mm}, 5 \mu \mathrm{m})$. The mobile phase consisted of dipotassium phosphate $\left(\mathrm{K}_{2} \mathrm{HPO}_{4}, 0.1 \mathrm{M}\right)$, monobasic potassium phosphate $\left(\mathrm{KH}_{2} \mathrm{PO}_{4}, 0.08 \mathrm{M}\right)$ and methanol, and was eluted isocratically at a flow rate of $0.5 \mathrm{ml} / \mathrm{min}$. The detector wavelength was set at $350 \mathrm{~nm}$ (excitation wavelength) and $430 \mathrm{~nm}$ (emission wavelength). Ascorbic acid was quantified using the external standard method. Results were reported as mg ascorbic acid/100 g FW of fruit.

\subsubsection{Determination of total carotenoids content (TCC)}

Total carotenoids extraction method was adapted from that described by Mertz et al. (2009). Two grams of sample was extracted with $100 \mathrm{ml}$ of extraction solvent (hexane/ethanol/acetone, 50:25:25 v/v/v) with magnetic stirring for $30 \mathrm{~min}$. The residue was separated from the liquid phase by filtration under vacuum with a sintered funnel coupled to a $250 \mathrm{ml}$ Buchner flask. The extract was transferred into a separatory funnel and successively washed three times with $25 \mathrm{ml}$ of distilled water in order to remove acetone and ethanol. The aqueous layer was discarded. The hexanic phase was transferred to a $50 \mathrm{ml}$ volumetric flask containing $15 \mathrm{~g}$ of anhydrous sodium sulfate. The volume was made up by hexane and the absorbance was read at $450 \mathrm{~nm}$ against a blank using a Perkin Elmer EZ 301 UV/VIS spectrophotometer.

\subsection{Statistical analysis}

The statistical analysis was computed using Statgraphics centurion 15.2.06 (Statpoint technologies, Inc., Virginia, USA). The data were analyzed for significant differences $(p \leq 0.05)$ by means of analysis of variance (ANOVA) and Duncan's multiple comparison tests. The data sets were also subjected to multivariate data analysis using principle component analysis (PCA) and hierarchical cluster analysis (CA). PCA was carried out by means of Uniwin Plus 6.1 (complementary module of Statgraphics centurion 15.2.06, Statpoint technologies, Inc., Virginia, USA). PCA is a standard tool in modern data analysis which is used to explore interdependencies among characteristics studied, and to identify variant groups with similar behaviour in each cultivar. This multivariate method reduces a large data matrix to a planar dimension, defined by two axes known as principal components. PCA summarizes correlated variables and facilitates the interpretation of the data set. In our case, all the criteria observed were treated as variables and constituted the rows of the data matrices. The results of PCA were given as a scores plot. Hierarchical cluster analysis (CA) was performed using the XLStat 2012.4.02 program (Addinsoft, New York, USA) to establish groups defined according to their similarities, and to compare them with the previous ones from PCA. The measure of similarity was evaluated by the Euclidean distance and the Ward method was the clustering algorithm. The Ward method consists in calculating the variances associated with all possible combinations between every two clusters. Then, it groups the two clusters that have the least increase in the variance of the joint group. In our study, all the characteristics observed were considered as variables. The results were displayed in dendrograms.

For both the PCA and CA methods, all data were normalized to avoid the influence of the different scales of the variables. They were centered by subtracting the mean and reduced by dividing by the standard deviation for every variable.

\section{Results and discussion}

\subsection{Fruit morphology and physical characteristics}

The morphological and physical characteristics of the fruits of the six mamey accessions studied are given in Table 1 .

The ratio of equatorial circumference to longitudinal circumference is useful to describe the shape of mamey fruit. Sonson fruits were characterized by elliptical geometry. This ratio for Pavé 11 was significantly higher than that of the other accessions. Pavé 11 fruits were found to be egg-shaped. The average fruit weight varies from one accession to another (Table 1). Those of fruits from the accessions Lézarde, Sonson and Pavé 11 were significantly higher than those of fruits from the accessions Antonio, Escouët and Ti Jacques. The mean weight of each of these two groups was significantly different, with $968 \mathrm{~g}$ and $610 \mathrm{~g}$ respectively. The highest average weight, that of Lézarde fruits $(1103 \pm 619 \mathrm{~g})$ was almost twice that of the Antonio fruits $(567 \pm 268 \mathrm{~g})$, the lowest. The average fruit weights in the present study were higher than those observed by Gervais and Lavigne (2007) (335 $\pm 101 \mathrm{~g}$ to $858 \pm 407 \mathrm{~g}$ ). This could be explained by our fruits coming from grafted trees.

Mamey fruits may contain one to four seeds. The seed number by fruit and the pulp adhesion to the seeds must be considered in the handling of mamey fruits during processing. The lowest average number of seeds by fruit was in the Sonson accession $(1.20 \pm 0.41)$, followed by Pavé $11(1.43 \pm 0.50)$ and Antonio $(1.57 \pm 0.73)$. These results are comparable to data published by Gervais and Lavigne (2007) and Mourão and Beltrati (2000). Also, the seeds are on average $7-21 \%$ of the fruit weight. Regarding 
Table 1

Average morphological and physical characteristics of 30 ripe fruits from the six mamey accessions studied.

\begin{tabular}{|c|c|c|c|c|c|c|}
\hline & Antonio & Lézarde & Sonson & Escouët & Ti jacques & Pavé 11 \\
\hline \multicolumn{7}{|l|}{ Morphological characteristics } \\
\hline Average ratio $\mathrm{EC} / \mathrm{LC}$ & $1,02 \pm 0,04^{\mathrm{a}}$ & $1,01 \pm 0,04^{\mathrm{a}}$ & $0,99 \pm 0,02^{\mathrm{a}}$ & $1,00 \pm 0,04^{\mathrm{a}}$ & $1,01 \pm 0,07^{\mathrm{a}}$ & $1,05 \pm 0,04^{b}$ \\
\hline Average fruit weight (g) & $567 \pm 268^{a}$ & $1104 \pm 620^{b}$ & $935 \pm 399^{b}$ & $649 \pm 292^{\mathrm{a}}$ & $613 \pm 246^{\mathrm{a}}$ & $864 \pm 264^{b}$ \\
\hline Average seed number & $1,57 \pm 0,73^{\mathrm{b}}$ & $1,70 \pm 0,79^{c}$ & $1,20 \pm 0,41^{\mathrm{a}}$ & $1,77 \pm 1,07^{\mathrm{bc}}$ & $1,87 \pm 0,97^{\mathrm{c}}$ & $1,43 \pm 0,50^{\mathrm{b}}$ \\
\hline Average fruit pulp (\%) & $53 \pm 11^{\mathrm{c}}$ & $64 \pm 14^{\mathrm{b}}$ & $64 \pm 12^{\mathrm{b}}$ & $49 \pm 15^{\mathrm{d}}$ & $60 \pm 10^{\mathrm{b}}$ & $67 \pm 20^{a}$ \\
\hline Average fruit seeds (\%) & $14 \pm 4^{\mathrm{b}}$ & $12 \pm 5^{c}$ & $7 \pm 2^{d}$ & $21 \pm 10^{\mathrm{a}}$ & $15 \pm 7^{\mathrm{b}}$ & $10 \pm 3^{c}$ \\
\hline Average fruit skin (\%) & $20 \pm 4^{\mathrm{c}}$ & $21 \pm 6^{c}$ & $24 \pm 7^{a}$ & $22 \pm 5^{b}$ & $20 \pm 5^{c}$ & $27 \pm 6^{\mathrm{a}}$ \\
\hline Average fruit firmness (N) & $56 \pm 12^{\mathrm{bc}}$ & $64 \pm 9^{d}$ & $51 \pm 9^{\mathrm{ab}}$ & $58 \pm 10^{c}$ & $46 \pm 12^{\mathrm{a}}$ & $59 \pm 12 c^{d}$ \\
\hline \multicolumn{7}{|l|}{ Average pulp colour } \\
\hline $\mathrm{L}^{*}$ & $68 \pm 3^{\mathrm{ab}}$ & $72 \pm 3^{c}$ & $72 \pm 4^{c}$ & $67 \pm 3^{a}$ & $67 \pm 3^{a}$ & $69 \pm 2^{\mathrm{b}}$ \\
\hline$a^{*}$ & $22 \pm 4^{\mathrm{a}}$ & $23 \pm 4^{\mathrm{a}}$ & $19 \pm 6^{a}$ & $20 \pm 5^{a}$ & $28 \pm 4^{\mathrm{b}}$ & $26 \pm 7^{b}$ \\
\hline $\mathrm{b}^{*}$ & $61 \pm 3^{a}$ & $74 \pm 3^{\mathrm{d}}$ & $77 \pm 5^{\mathrm{e}}$ & $68 \pm 6^{b}$ & $72 \pm 5^{\mathrm{bc}}$ & $73 \pm 4 c^{d}$ \\
\hline Average seed adherence to pulp & $3,33 \pm 1,90^{\mathrm{a}}$ & $3,17 \pm 1,96^{a}$ & $1,58 \pm 1,54^{\mathrm{a}}$ & $4,75 \pm 0,76^{\mathrm{b}}$ & $2,75 \pm 1,78^{\mathrm{a}}$ & $3,75 \pm 1,27^{\mathrm{a}}$ \\
\hline
\end{tabular}

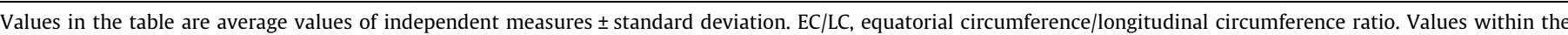
same row with different superscript letters are significantly different $(P<0.05$, Duncan's test.

the pulp adherence to the seeds, Sonson pulp, followed by Ti Jacques, had the lowest adherence, with mean values of 1.58 and 2.75 , respectively. Escouët pulp was characterized by strong adherence to the seeds with a mean value of 4.75 . The respective average fruit pulp proportions for Pavé 11, Lézarde, Sonson and Ti Jacques were significantly higher than those of the two other accessions. The ripe Mamey fruits are also characterized by a rather firm texture in the hand. Whole fruit firmness varied depending on the mamey accession. Lézarde fruits, followed by Pavé 11 and Escouët, had the highest firmness values, with mean values of 64,59 and $58 \mathrm{~N}$ respectively. The whole mamey fruit firmness ranged from 45 to $64 \mathrm{~N}$, which was comparable to that reported for the apple (57) (Hoehn, Gasser, Guggenbühl, \& Künsch, 2003).

The colour of the mamey fruit pulp was dominated by a yellow to orange hue. The fruit pulp from the Sonson and Lézarde accessions was brighter than that of the other accessions, with $L$ values of 72.56 and 71.69 respectively. The yellow colour was represented by high $\mathrm{b}^{*}$ values, and the orange colour was associated with high $a^{*}$ values. The fruit pulp from the Pavé 11 and Ti Jacques accessions was characterized by an orange colour with a* values of 25.87 and 27.70 respectively. The yellow pulp of Sonson fruits was distinct, with the lowest $a^{*}$ value (19.34) and the higher $b^{*}$ value (76.88).

It appears that the fruits studied comprised just over half pulp by weight (50 to $60 \%$ ), which is slightly lower than the proportions reported by Gervais and Lavigne (2007). The fruits are protected by a thick skin with a leathery appearance, and weighed $20-27 \%$ of the whole fruit.

\subsection{Physico-chemical characteristics of the fruit pulp}

The physico-chemical determinations are presented in Table 2. Statistically significant variations were observed between the accessions for the $\mathrm{pH}$. The pulp of the fruits from the Antonio and Sonson accessions had the lowest $\mathrm{pH}$, followed by Ti Jacques with $\mathrm{pH}$ values of $3.41,3.42$ and 3.63 respectively. Escouet, Pavé
11 and Lézard were a homogenous group with a slightly higher $\mathrm{pH}$ than the other accessions. Similar values were also reported by Manzano-Mendez and Dris (2001). The SSC consisted mainly of sugars. The value for Ti Jacques was found to be greater than that of the other accessions. Regarding TA, it was observed that Sonson registered the highest values. The flavour, i.e., the balance between sugar and acidity, was assessed by SSC/TA ratio. Lézarde (4.99), followed by Ti Jacques (3.87), Escouët (3.49) and Pavé 11 (3.25) were sweeter than Sonson and Antonio fruits. SSC/AT ratios of Escouët, Lézarde, Pavé 11 and Ti Jacques fruits in the present study were much greater than the values reported by Gervais and Lavigne (2007). Mamey is a pulpy fruit, suitable for nectar preparation, with TDM varying from $11.69 \mathrm{~g} / 100 \mathrm{~g}$ to $16.33 \mathrm{~g} / 100 \mathrm{~g}$. This is in agreement with data observed in food composition tables. Ti Jacques fruits had the highest TDM content, whereas Sonson fruits had the lowest values.

\subsection{Biochemical characteristics}

The biochemical characteristics are summarized in Table 1 . The carotenoids pigments are responsible for the external and internal coloration of many foods. Ti Jacques and Pavé 11 pulps were characterized by the highest total carotenoids content (TCC), with values of $3.94 \mathrm{mg} / 100 \mathrm{~g}$ and $4.63 \mathrm{mg} / 100 \mathrm{~g}$ respectively. This is less than that reported by De Rosso and Mercadante (2007) (6.25 mg/100 g) and Giuffrida et al. (2015) (14.5 mg/100 g). The TCC of Ti Jacques and Pavé 11 were higher than that of coloured tropical fruits, such as acerola $(1.40 \mathrm{mg} / 100 \mathrm{~g})$ (Rufino et al., 2010), mango $(0.553 \mathrm{mg} / 100 \mathrm{~g})$, red watermelon $(0.592 \mathrm{mg} /$ $100 \mathrm{~g})$, papaya $(0.440 \mathrm{mg} / 100 \mathrm{~g})$ and orange $(0.275 \mathrm{mg} / 100 \mathrm{~g})$ (Setiawan, Sulaeman, Giraud, \& Driskell, 2001).

The total phenolic content (TPC) differed significantly between the six accessions studied. The highest TPC was found in Escouët (143 mg/100 g), followed by Pavé 11 ( $137 \mathrm{mg} / 100 \mathrm{~g})$. The difference observed among the accessions studied in terms of TPC is

Table 2

Physico-chemical characteristics of the six mamey accessions studied.

\begin{tabular}{|c|c|c|c|c|c|c|}
\hline & Sonson & Lézarde & Pavé 11 & Antonio & Escouët & Ti Jacques \\
\hline $\mathrm{pH}$ & $3.42 \pm 0.17^{\mathrm{a}}$ & $3.86 \pm 0.13^{c}$ & $3.78 \pm 0.09^{c}$ & $3.41 \pm 0.01^{\mathrm{a}}$ & $3.80 \pm 0.05^{c}$ & $3.63 \pm 0.12^{\mathrm{b}}$ \\
\hline SSC & $9.09 \pm 1.47^{a}$ & $11.15 \pm 1.85^{c}$ & $9.95 \pm 2.04^{b}$ & $10.39 \pm 0.17^{b}$ & $11.09 \pm 0.37^{c}$ & $13.64 \pm 1.74^{\mathrm{d}}$ \\
\hline TA & $5.16 \pm 1.41^{\mathrm{e}}$ & $2.62 \pm 1.00^{\mathrm{a}}$ & $3.13 \pm 0.47^{b}$ & $4.57 \pm 0.88^{d}$ & $3.23 \pm 0.51^{\mathrm{b}}$ & $3.82 \pm 0.95^{c}$ \\
\hline $\mathrm{SSC} / \mathrm{TA}$ & $1.99 \pm 0.99^{\mathrm{a}}$ & $4.99 \pm 2.21^{\mathrm{c}}$ & $3.25 \pm 0.82^{\mathrm{b}}$ & $2.36 \pm 0.52^{\mathrm{b}}$ & $3.49 \pm 0.39^{c}$ & $3.87 \pm 1.49^{\mathrm{d}}$ \\
\hline TDM & $11.69 \pm 1.72^{\mathrm{a}}$ & $14.89 \pm 2.24^{\mathrm{c}}$ & $14.03 \pm 1.68^{c}$ & $13.39 \pm 0.02^{b}$ & $13.51 \pm 0.10^{b}$ & $16.33 \pm 2.48^{\mathrm{d}}$ \\
\hline
\end{tabular}

SSC, soluble solids content expressed as ${ }^{\circ}$ Brix; TA, titratable acidity expressed as meq/100 ml sample, TDM, total dry matter expressed as g/100 g fresh weight.

Values with different superscript letters are significantly different within the same row $(\mathrm{P}<0.05$, Duncan's test).

Results are expressed in means \pm standard deviation. 
probably due to plant genotype, because all grafted plants were of the same age and were grown in the same location using similar horticultural practices. Scalzo, Politi, Pellegrini, Mezzetti, and Battino (2005) reported that plant genotype affects total phenolic content in fruit. According to our results, TPC of mamey fruits (varying from $90 \mathrm{mg} / 100 \mathrm{~g}$ to $143 \mathrm{mg} / 100 \mathrm{~g}$ ) was lower than that of strawberry (264 mg/100 g), lychee (222 mg/100 g), grape $(195 \mathrm{mg} / 100 \mathrm{~g})$, apricot $(180 \mathrm{mg} / 100 \mathrm{~g})$ and apple $(179 \mathrm{mg} /$ $100 \mathrm{~g}$ ); while our measured TPCs were higher than that of tropical fruit, such as passion fruit $(71 \mathrm{mg} / 100 \mathrm{~g})$, mango $(68 \mathrm{mg} / 100 \mathrm{~g})$, banana $(51 \mathrm{mg} / 100 \mathrm{~g}$ ) and pineapple $(47 \mathrm{mg} / 100 \mathrm{~g}$ ) (Brat et al., 2006).

Flavonoids are the most common phenolic substances in fruits and vegetables. These components may act as antioxidants and contribute to reducing the risks of some disease in consumers, such as cancer or cardiovascular disease (Levaj, Daragovic-uzelac, Bursackovacevic, \& Krasnici, 2009). Among the mamey accessions studied, the pulp from Ti Jacques fruits had the highest total flavonoids content (TFC) $(9.90 \mathrm{mg} / 100 \mathrm{~g})$, followed by Pavé 11 and Lézarde ( $5.08 \mathrm{mg} / 100 \mathrm{~g}$ and $4.10 \mathrm{mg} / 100 \mathrm{~g}$ respectively). These values were comparable to those published for pineapple $(3.24 \mathrm{mg} / 100 \mathrm{~g})$, acerola $(9.6 \mathrm{mg} / 100 \mathrm{~g})$ and yellow mombin (7.1 mg/100 g); whereas our values were lower than those reported for banana $(23.7 \mathrm{mg} / 100 \mathrm{~g})$, guava $(40.6 \mathrm{mg} / 100 \mathrm{~g})$, acai $(91.3 \mathrm{mg} / 100 \mathrm{~g})$ and apple $(16 \mathrm{mg} / 100 \mathrm{~g}$ ) (Alothman, Bhat, \& Karim, 2009; Rufino et al., 2010; D’Abrosca et al., 2007).

Regarding ascorbic acid content (AAC), Sonson fruits, the most acidic tested sample in terms of $\mathrm{pH}$ and titrable acidity were found to have a significantly higher value than those of other accessions, with $7.28 \mathrm{mg} / 100 \mathrm{~g}$. The values reported in the present study were lower than those observed in the food composition table (varying from 10.2 to $22 \mathrm{mg} / 100 \mathrm{~g}$ ) (Morton, 1962; USDA, 2012).

\subsection{Classification of mamey accessions by PCA and CA}

A PCA was carried out to determine a classification of the mamey accessions studied, and investigate the correlations between the parameters studied.

Strong positive correlation coefficients were observed between the fruit weight and the $L^{*}$ colour value $\left(R^{2}=0.90\right)$, the TDM and the $a^{*}$ colour value $\left(\mathrm{R}^{2}=0.93\right)$, and between the TPC and the pulp adherence to seeds $\left(\mathrm{R}^{2}=0.90\right)$. The $a^{*}$ colour value was positively correlated with TFC $\left(R^{2}=0.89\right)$ and the TCC $\left(R^{2}=0.79\right)$. Flavonoids and carotenoids pigment are responsible for the external and internal coloration of many fruits. Therefore these components were primarily responsible for the expression of the orange colour in mamey apple. A positive correlation was also observed between the TDM and TFC $\left(R^{2}=0.89\right)$, suggesting that fruits with a high TDM content (or low moisture content) were characterized by high TFC. The pulp adherence to seeds was negatively correlated with the pulp/peel ratio $\left(R^{2}=-0.89\right)$. The negative correlation between the pulp/seed ratio and the seed number $\left(R^{2}=-0.80\right)$ was expected, and proved the reliability of the statistical analysis.

According to the PCA results, the first three principal components $(\mathrm{PC})$ jointly explained $84.60 \%$ of the total variability observed among the 18 variables studied. As shown by the PCA biplot, mamey accessions were grouped according to their physical, physico-chemical and biochemical characteristics. PC1 explained $41.3 \%$ of the variance, whereas PC2 explained 25.6\% (Fig. 1A). Sonson (negative PC1 dimension) was located on the left side of the PCA biplot, because its fruits were large and pulpy with a bright pulp rich in ascorbic acid. By contrast, Antonio, Escouët, Pavé 11 and Ti Jacques (positive PC1 dimension) were grouped on the right side of the biplot due to the pulp adherence to the seeds, seed number and TPC which positively contributed to the PC1. Lézarde was close to the center of the PCA biplot. Pavé 11, Ti Jacques and Lézarde (negative PC2 dimension) were correlated with the ratio SSC/TA, the TFC and the TCC, which were negatively loaded in PC2. PC3 explained $17.7 \%$ of the variance and was mainly related to firmness with a negative load (Fig. 1B). Lézarde (negative PC3 dimension) was correlated with this variable. From the PCA biplot, four groups of mamey accessions were observed, i.e., Sonson, Antonio-Escouët, Lézarde and Pavé 11-Ti Jacques.

- Sonson presented large and pulpy fruits with the fewest seeds in number and lowest weight. The pulp adherence to the seeds was partial, the lowest. Its pulp was the most acidic. So its fruits had suitable characteristics for the manufacturing of yellow coloured mamey products. All of which makes Sonson pulp distinct.

- Antonio and Escouët fruits were characterized by small and pulpy fruits with many seeds compared to those of other accessions. Although the mean weight of Antonio and Escouët fruits were comparable to the values reported in the literature.

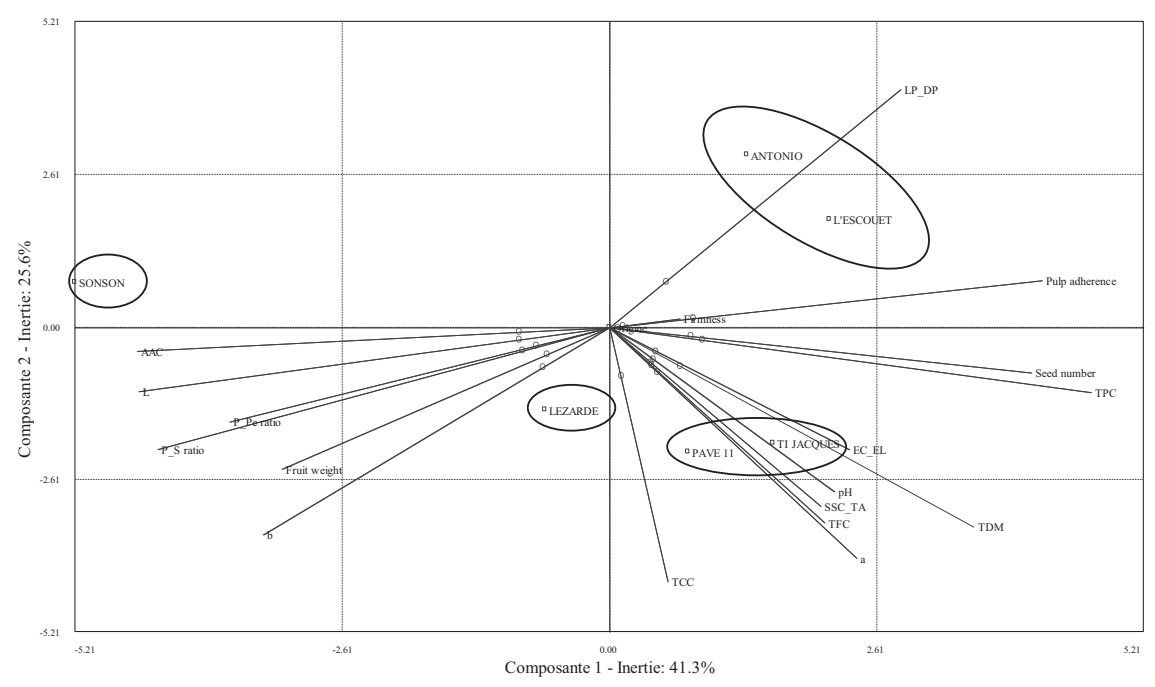

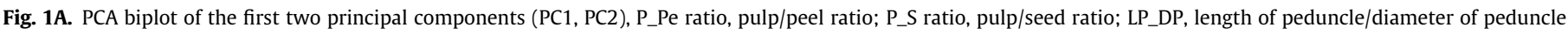

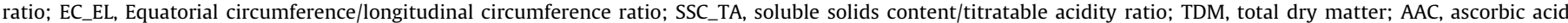

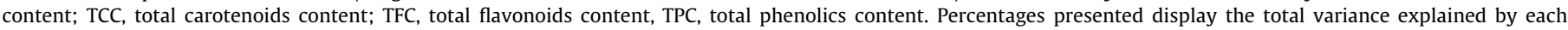
principal component. 


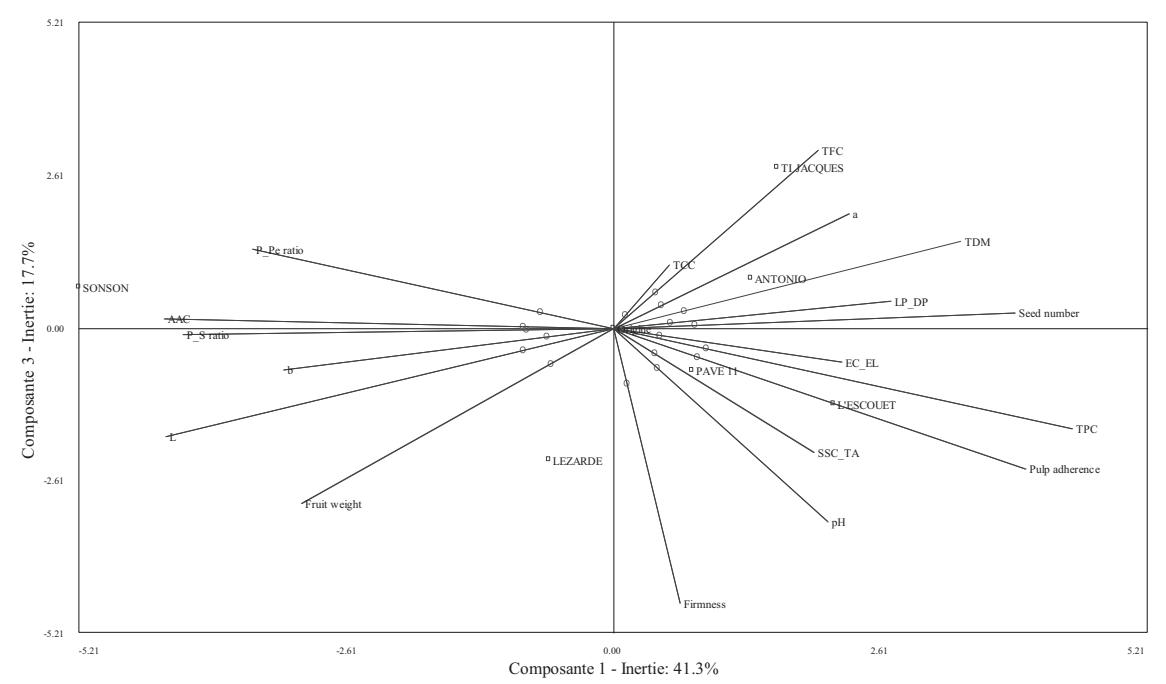

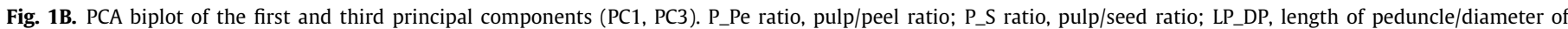

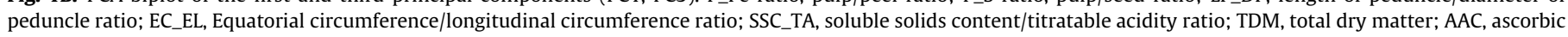

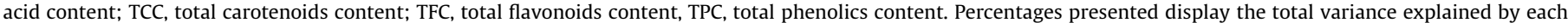
principal component.Biplot.

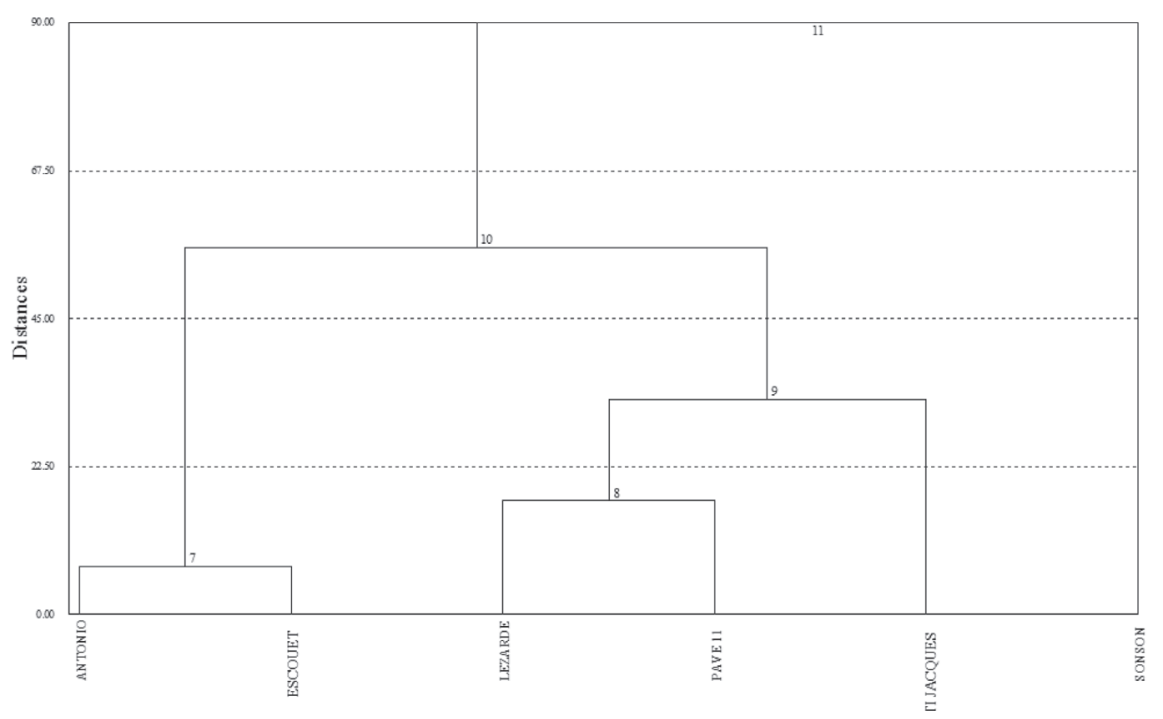

Fig. 2. Dendrogram using ward's minimum variance cluster analysis.

However, Escouët was the highest in TPC with a high adherence of seeds to pulp. This latter trait is negative for fruit processing.

- The pulp colour of Pavé 11 and Ti Jacques was dominated by an orange hue. These accessions were good for consumption, containing low levels of acids, a high sugar/acid ratio and high level of TFC and TCC.

- Lézarde had the firmest fruits and was suitable for export. Its large and pulpy fruits were also interesting in terms of processing.

A CA (Cluster Analysis) was conducted in order to classify the mamey accessions studied, and to compare the results with the previous ones from PCA. The differences seem slight. The dendrogram is presented in Fig. 2. From the dendrogram, mamey accessions could be grouped into four classes, i.e., Sonson, Antonio-Escouët, Lézarde-Pavé 11 and Ti Jacques. Similar trends with the PCA were observed, Sonson was the most isolated cluster, Antonio and Escout were always close. Ti Jacques forms a cluster that is not far from Lézarde and Pavé 11. These latter three form a group rather close to the intersection of the PCA axes, except that
Ti Jacques is singularly orange coloured with small fruits. The slight difference was probably due to the fact that the fruit weight was the major contributor to the formation of the classes obtained by CA. Technologically, Pavé 11 and Lézarde accessions form a homogeneous group whose fruit pulp can be processed jointly.

\section{Conclusion}

Considerable variability in physical and chemical characteristics was observed between the six mamey accessions studied. The average fruit weight per accession varies from single to double with a high coefficient of variation of between 30 and 56\%. Also, the average pulp percentage of the fruits went from 50 to $67 \%$.

Five of the six accessions we have studied were grafted trees, cultivated in similar conditions; they were previously studied by Gervais and Lavigne (2007) as individual cultivars in various environments. The fruits we have studied were much bigger (20 to $100 \%$ heavier) than those from the corresponding cultivars described by Gervais and Lavigne (2007), except for Ti-Jacques 
accession which was $12 \%$ lighter. Also, in our samples, the seed number in each fruit was always higher and more adherent to the pulp, partially for all our accessions, except for one where the adherence was total. Gervais and Lavigne reported no adherence for two accessions we have studied (Sonson and Ti Jacques). However, the pulp ratio of the fruit from the grafted trees was a little lower in comparison to the values measured on the fruits from the corresponding cultivars studied by Gervais and Lavigne (2007). Also, the coefficients of variation of the average fruit weights from the cultivars were lower compared to those of the fruits from the grafted trees. So, the variability seems higher for the grafted fruits than for the fruits from the accessions. The larger fruit size harvested under the grafted trees could be due to better bioclimatic conditions (water, light, soil) of cultivation than for the accessions at their respective origins. Thus, the differences between the accessions we have reported were probably due to the plant genotype, since all the accessions were grown in the same geographical field using similar horticultural practices. We have established for the first time total phenolic compounds and total flavonoids contents in the pulp of mamey apple fruits.

According to our results, the post-harvest processing routes for each accession or group of accessions could be different. Lézarde was interesting in terms of processing and export because of its firm, large and pulpy fruits. The pulp of Lézarde and Pavé 11 may be processed together. Pavé 11, Lézarde and Ti Jacques pulps were found to be good for direct consumption giving sweeter fruits with high total phenolics and total carotenoids contents. Ti Jacques could give orange coloured products. Sonson gives big pulpy, acidic fruits, with few bioactive compounds; this accession is suitable for mixtures with other fruits providing bioactive compounds. Escouët seems the least suitable for processing, because of the strong adherence of seeds to the pulp and its high seeds content. More studies must be conducted on the antioxidant activities and functional properties of Mammea americana fruit pulp and their evolution during post-harvest treatments.

\section{Acknowledgments}

The authors would like to thank the Regional council of Martinique for its financial support, and the French Agricultural Research Centre for International Development (CIRAD) for allowing access to the six accessions.

\section{References}

Al-Maiman, S. A., \& Ahmad, D. (2002). Changes in physical and chemical properties during pomegranate (Punica granatum L.) fruit maturation. Food Chemistry, 76 437-441.

Alothman, M., Bhat, R., \& Karim, A. A. (2009). Antioxidant capacity and phenolic content of selected tropical fruits from Malaysia, extracted with different solvents. Food Chemistry, 115, 785-788.

Bartolomé, A. P., Rupérez, P., \& Fúster, C. (1995). Pineapple fruit: morphological characteristics, chemical composition and sensory analysis of Red Spanish and Smooth Cayenne cultivars. Food Chemistry, 53, 75-79.

Bashir, H. A., \& Abu-Goukh, A.-B. A. (2003). Compositional changes during guava fruit ripening. Food Chemistry, 80, 557-563.

Boulogne, I., Germosen-Robineau, L., Ozier-Lafontaine, H., Jacoby-Koaly, C., Aurela L., \& Loranger-Merciris, G. (2011). Acromyrmex octospinosus (Hymenotera: Formicidae) managementEllipsis Part1: Effects of TRAMIL's insecticidal plant extracts. Pest Management Science, 68, 313-320.

Brat, P., Georgé, S., Bellamy, A., Du Chaffaut, L., Scalbert, A., Mennen, L., ... Amiot, M. J. (2006). Daily polyphenol intake in France from fruit and vegetables. The Journal of Nutrition, 136, 2368-2373.

Campbell, R. J. (2005). Collecting Mammea Americana L. in tropical America: Potential for Florida. Proceedings of the Florida State Horticultural Society, 118 242-243.

Chew, L. Y., Nagendra Prasad, K., Amin, A., Azrina, A., \& Lau, C. Y. (2011). Nutritional composition and antioxidant properties of Canarium odontophyllum Miq. (dabai) fruits. Journal of Food Composition and Analysis, 24, 670-677.

Crombie, L., Games, D. E., Hskins, N. J., \& Reed, G. F. (1972). Extractives of Mammea amricana L. Part V. The insecticidal compounds. Journal of the Chemical Society, Perkin Transaction, 1, 2255-2260.
D’abrosca, D., Pacifico, S., Cefarelli, G., Mastellone, C., \& Fiorentino, A. (2007). 'Limoncella' apple, an Italian apple cultivar: Phenolic and flavonoid contents and antioxidant activity. Food chemistry, 104, 1333-1337.

De Rosso, V. V., \& Mercadante, A. Z. (2007). Identification and quantification of carotenoids, by HPLC-PDA-MS/MS, from amazonian fruits. Journal of Agricultural and Food Chemistry, 55, 5062-5072.

Dunthorn, M. (2004). Cryptic dioecy in Mammea (Clusiaceae). Plant Systematics and Evolution, 249, 191-196.

Gallo, L. G., Allee, L. L., \& Gibson, D. M. (1996). Insecticiadal effectiveness of Mammea America (Guttiferae) extracts on larvae of Diabrotica virgifera) (Coleoptera: Chrysomelidae) and Trichoplusia ni (Lepidoptera: Noctuidae). Economic Botany, 50(2), 236-242.

Georgé, S., Brat, P., Alter, P., \& Amiot, M. J. (2005). Rapid determination of polyphenols and vitamin $C$ in plant-derived products. Journal of Agricultural and Food Chemistry, 53, 1370-1373.

Gervais, L., \& Lavigne, C. (2007). Mamey (Mammea americana L.) in Martinique Island: an inheritance to be developed. Fruits, 62, 135-142.

Giuffrida, D., Menchaca, D., Dugo, P., Donato, P., Cacciola, F., \& Murillo, E. (2015). Study of the carotenoid composition in membrillo, guanabana toreta, jobo and mamey fruits. Fruits, 70(3), 163-172.

Hoehn, E., Gasser, F., Guggenbühl, B., \& Künsch, U. (2003). Efficacy of instrumental measurements for determination of minimum requirements of firmness, soluble solids, and acidity of several apple accessions in comparison to consumer expectations. Postharvest Biology and Technology, 27, 27-37.

Jones, M. A., \& Plank, H. K. (1945). Chemical nature of the insecticidal principle in mamey seed. Journal of the American Chemical Society, 67, 2266-2267.

Lamaison, J. L. C., \& Carnet, A. (1990). Teneurs en principaux flavonoids des fleurs de Crataegeus monogyna Jacq et de Crataegeus laevigata (Poiret D. C) en fonction de la vegetation. Pharmaceutica Acta Helvetiae, 65, 315-320.

Le Bellec, F., \& Le Bellec, V. (2007). Le verger tropical Cultiver les arbres fruitiers (second ed.). Orphie.

Levaj, B., Daragovic-uzelac, V., Bursackovacevic, D., \& Krasnici, N. (2009). Determination of flavonoids in pulp and peel of mandarin fruits. Agriculturae Conspectus Scientificus, 74, 221-225.

Manzano-Mendez, J.E., Dris, R. (2001). Effect of storage atmosphere and temperature on soluble solids in mamey amarillo (Mammea americana L.) fruits. In Proceedings of the 4th International Conference on Postharvest Science (Issue 553, pp. 675-676). Acta Horticulturae: Jerusalem, Israel.

Melendez, P. A., \& Capriles, V. A. (2002). Molluscidal activity of plants from PuertoRico. Annals of tropical medicine and parasitology, 96(2), 209-218.

Mertz, C., Gancel, A. L., Gunata, Z., Alter, P., Dhuique-Mayer, C., Vaillant, F., ... Brat, P. (2009). Phenolic compounds, carotenoids and antioxidant activity of three tropical fruits. Journal of Food Composition and Analysis, 22, 381-387.

Morales, A. L., \& Duque, C. (2002). Free and glycosidically bound volatiles in the mammee apple (Mammea americana) fruit. European Food Research and Technology, 215, 221-226.

Morton, J.F. (1962). The mamey. In Proceedings of Florida state horticultural society. (Vol. 75, 400-407). Morton Collectanea, University of Miami: Coral Gables.

Mourão, K. S. M., \& Beltrati, C. M. (2000). Morphology and anatomy of developing fruits and seeds of Mammea americana L. (Clusiaceae). Revista Brasileira de Biologia, 60, 701-711.

NF Norme Française (2011). NF V 03-135. Foodstuffs - Determination of vitamin C by high performance liquid chromatography. Association Française de Normalisation (AFNOR), La Plaine Saint-Denis Cedex.

Reyes-Chilpa, R., Estrada-Muňiz, E., Vega-Avila, E., Abe, F., Kinjo, J., \& HernandezOrtega, F. (2008). Trypanocidal constituents in plants. 7. Mammea-type coumarins. Mem Instituto Oswaldo Cruz, Rio de Janeiro, 103, 5, 431-436.

Rufino, M. S. M., Alves, R. E., de Brito, E. S., Pérez-Jiménez, J., Saura-Calixto, F., \& Mancini-Filho, J. (2010). Bioactive compounds and antioxidant capacities of 18 non-traditional tropical fruits from Brazil. Food Chemistry, 121, 996-1002.

Scalzo, J., Politi, A., Pellegrini, N., Mezzetti, B., \& Battino, M. (2005). Plant genotype affects total antioxidant capacity and phenolic contents in fruit. Nutrition, 21, 207-213.

Setiawan, B., Sulaeman, A., Giraud, D. W., \& Driskell, J. A. (2001). Carotenoid content of selected indonesian fruits. Journal of food composition and analysis, 14 169-176.

Singleton, V. L., \& Rossi, J. A. Jr., (1965). Colorimetry of total phenolics with phosphomolybdic-phosphotungstic acid reagents. American Journal of Enology and Viticulture, 16, 144-158.

Toma, W., Hiruma-Lima, C. A., Guerrero, R. O., \& Souza-Brito, A. R. M. (2005). Preliminary studies of Mammea americana L. (Guttiferae) bark/latex extract point to an effective antiulcer effect on gastric ulcer models in mice. Phytomedicine, 12, 345-350.

U.S. Department of agriculture, Agricultural Research Service. (2012). USDA Nutrient Database for Standard Reference, Release 25. Retrieved May 3, 2013 from Nutrient Data Laboratory Homepage: ndb.nal.usda.gov/ndb/foods/show/ 2287.

Yahia, E. M., \& Guttierez-Orozco, F. (2011). Mammey-apple (Mammea americana L.) Postharvest biology and technology of tropical and subtropical fruits, 3 Cocona to mango. Food Science Technology and Nutrition (208, pp. 474-481). Woodhead publishing.

Yang, H., Jiang, B., Reynertson, K. A., Basile, M. J., \& Kennelly, E. J. (2006). Comparative analysis of bioactive Mammea coumarins from seven parts of Mammea americana by HPLC-PDA with LC-MS. Journal of Agricultural and Food Chemistry, 54, 4114-4120. 